\title{
Statistical analysis of dental variation in the Oligocene equid Miohippus (Mammalia, Perissodactyla) of Oregon
}

\author{
Nicholas A. Famoso ${ }^{1,2,3}$ \\ ${ }^{1}$ Department of Earth Sciences, 1272 University of Oregon, Eugene, OR 97403, USA 〈nfamoso2@uoregon.edu〉 \\ ${ }^{2}$ University of Oregon Museum of Natural and Cultural History, 1680 E. 15 ${ }^{\text {th }}$ Ave., Eugene, OR 97403, USA 〈nfamoso2@uoregon.edu〉 \\ ${ }^{3}$ John Day Fossil Beds National Monument, National Park Service, 32651 Hwy 19, Kimberly, OR 97848, USA 〈nicholas_famoso@nps.gov〉
}

\begin{abstract}
As many as eight species of the "anchitherine" equid Miohippus have been identified from the John Day Formation of Oregon, but no statistical analysis of variation in these horses has yet been conducted to determine if that level of diversity is warranted. Variation of the anterior-posterior length and transverse width of upper and lower teeth of Turtle Cove Member Miohippus was compared to that of M. equinanus, Mesohippus bairdii, Equus quagga, and Tapirus terrestris using $t$ tests of their coefficients of variation $(V)$. None of the $t$ tests are significant, indicating that the variation seen in Turtle Cove Miohippus is not significantly different from any of the populations of other perissodactyls examined in this study. Data also indicate that Mesohippus is present in the Turtle Cove Member. Additionally, hypostyle condition, used to diagnose all species of Miohippus, was found to be related to stage of wear using an ordered logistic regression. Only two species of equid, one Miohippus and one Mesohippus, in the Turtle Cove Member can be identified, therefore only Miohippus annectens, the genotype and first species described from the region, can be recognized as the sole Miohippus species known from the Turtle Cove assemblage. There are insufficient data to determine which species of Mesohippus is present. The dependence of hypostyle condition on crown height in Miohippus implies that wear stage must also be considered in investigations of dental morphology in the "Anchitheriinae."
\end{abstract}

\section{Introduction}

Quantifying variation in extinct species is an important first step in understanding the paleoecology of extinct organisms; the number of species present in an assemblage must be known before testing for changes in paleoecological relationships such as rates of turnover and extinction. Quantifying variation in species of terrestrial fossil vertebrates can be exceptionally difficult because large sample sizes and complete skeletal material are rarely recovered. Utilizing taxa that are phylogenetically related, ecologically similar, and known from more complete material can improve understanding of population variation.

Historically, eight species of the equid genus Miohippus Marsh, 1874 have been named from the Turtle Cove Member of the John Day Formation (Osborn, 1918). Recent work has suggested that a smaller genus of equid, Mesohippus Marsh, 1875 , is also present in this section (Albright et al., 2008). Most recently, authors have refrained from identifying species, instead identifying genera of equids from this section (Albright et al., 2008). However, little work has been done to examine, quantify, and statistically test the level of variation seen within the equid assemblage in the John Day Basin. This emphasizes the need to determine the number of verifiable species in the Turtle Cove assemblage. If a single species of equid is present in an assemblage, then the variation in linear morphological measurements would be similar to that observed for extant perissodactyl species. Additionally, morphological dental characters that are phylogenetically informative should be stable within species regardless of the animal's individual age.

Equid dental material in the John Day Formation is common and easily identifiable, consisting of skulls, partial palates, complete and partial jaws, and isolated teeth. This material was reexamined from the Turtle Cove Member, comparing the coefficients of variation $(V)$ with a $t$ test to determine if the variation seen in John Day Miohippus is similar to variation seen in extant species of perissodactyls. The hypostyle condition, an important dental character used to distinguish species in Miohippus, was tested using an ordered logistic regression to determine if it varies with wear. The hypostyle, an enamel structure located on the distal end of the second premolar through third molar, has three morphological states, or conditions, including a ridge, an anterior projection, and an enamel lake (Prothero and Shubin, 1989). John Day Miohippus was compared to related extant taxa and well-studied extinct taxa.

\section{Geologic setting}

The John Day Formation is distributed throughout eastern and central Oregon (Fig. 1) and is currently subdivided into seven members: Big Basin, Turtle Cove, Kimberly, Haystack Valley, Balm Creek, Johnson Canyon, and Rose Creek (Retallack et al., 2000; Hunt and Stepleton, 2004; Albright et al., 2008; Fig. 2). 


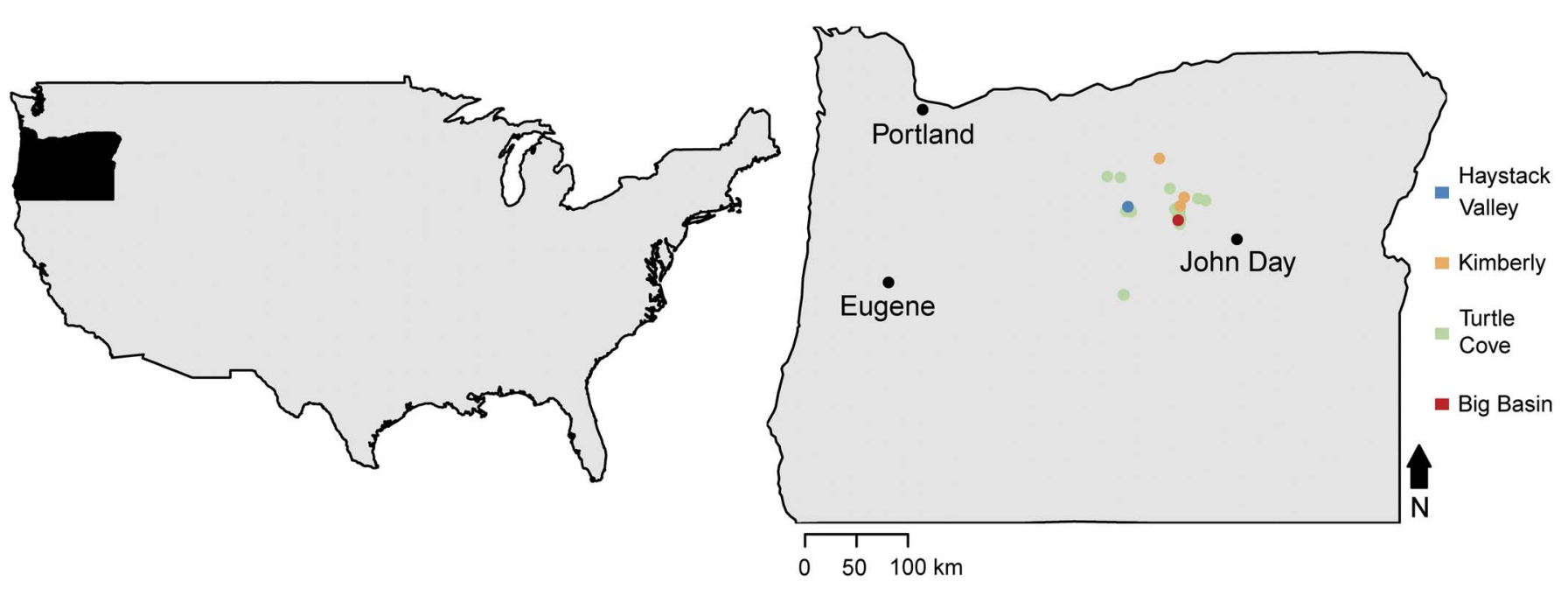

Figure 1. Distribution of localities utilized in this study. Localities are color coded by member; localities with unknown stratigraphy are not mapped. The locations of Portland, Eugene, and John Day are marked. Oregon is highlighted in black on the map of the United States of America.

This study focuses primarily on the equid faunal assemblage of the Turtle Cove Member (30.8-25.9 Ma), which consists of $\sim 400 \mathrm{~m}$ of section that Albright et al. (2008) divided into 14 lithostratigraphic subunits (A-K2; Fig. 2). Included within the member are several dated tuffs and the Picture Gorge ignimbrite-a super-volcanic event related to the Yellowstone hotspot (Seligman et al., 2014). The faunas of the Turtle Cove Member are assigned to the Whitneyan and Arikareean (subages Ar1 and Ar2) North American Land Mammal Ages (Albright et al., 2008). Specimens from the lower Big Basin Member and the higher Kimberly and Haystack Valley members are also included in this study, but these samples are much smaller than those of the Turtle Cove Member.

\section{Taxonomic background}

Miohippus is a genus of relatively moderate-sized equid $(\sim 53.8 \mathrm{~kg}$, M1-3 length $=34-50 \mathrm{~mm})$ belonging to the paraphyletic subfamily "Anchitheriinae" Leidy, 1869 (MacFadden, 1986; Prothero and Shubin, 1989; MacFadden 1998). Miohippus is coeval with the smaller Mesohippus and the larger Kalobatippus, Osborn, 1915, all of which are members of "Anchitheriinae" (MacFadden, 1998). Miohippus is considered to be distinct from Mesohippus based on the presence and condition of the articular facet on the third metatarsal, which articulates with the cuboid, larger hypostyles (Fig. 3); a longer face; and a deeper facial fossa (Prothero and Shubin, 1989; MacFadden, 1998); however, these two genera are difficult to distinguish (Stirton, 1940). Species within Miohippus in the Great Plains are diagnosed primarily on the basis of tooth-row length and hypostyle condition (Prothero and Shubin, 1989). Often, multiple hypostyle conditions can be observed in the same individual (Prothero and Shubin, 1989; Fig. 3). The Great Plains species have been the subject of more intensive study than the John Day species. However, this does not mean that the currently recognized Great Plains species are more likely to be valid than the John Day species. Further character and variation analyses of the Great Plains material may reduce the number of recognized species.
There are currently 16 species of Miohippus considered valid in North America. Of these, eight species have been named from the John Day Formation (Miohippus annectens Marsh, 1874; M. condoni [Leidy, 1870]; M. anceps [Marsh, 1874]; M. equiceps [Cope, 1878]; M. primus Osborn, 1918; M. quartus Osborn, 1918; M. acutidens [Sinclair, 1905]; and M. equinanus Osborn, 1918) (Prothero and Shubin, 1989; MacFadden, 1998). Many of the characters that diagnose these species are present in the molars and premolars. These characters include the anterior-posterior length and transverse width of molars and premolars, the texture of the enamel, and the morphology of the protoconules, metaconules, hypostyles, cingula, tubercal, paracone, metacone, hyperconulid, medivallum cusps, protoloph, protoconule, metaloph, ectoloph and parastyle (Osborn, 1918; Prothero and Shubin, 1989). The relative size of the M3 versus the M1-2 and the morphology of the incisors and canines have also been invoked as a diagnostic character (Osborn, 1918). The position of the orbit, dorsal preorbital fossa (DPOF) depth, lacrimal fossa depth, position of the infraorbital foramen, malar morphology, and muzzle shape have also been used to diagnose species (Osborn, 1918). The morphology of postcrania is only described in M. equinanus, and includes the metatarsals and cuboid (Osborn, 1918). The validity of many of these characters could be evaluated using geometric morphometric analyses, however before studies of that type can be undertaken it is necessary to quantify and understand the range of variation these characters display. This study helps to lay the foundation for those future studies. It is important to note that $M$. condoni is only known from a partial $\mathrm{dp}^{3}$ that is about the same size as M. annectens and M. anceps (Osborn, 1918). Osborn (1918) stated that Marsh's (1874) description of Miohippus (= Anchitherium) anceps does not follow the morphology of the type specimen.

Only dental characters can be compared among these eight species, and most species do not have descriptions of cranial or postcranial morphology (Osborn, 1918; Prothero and Shubin, 1989). It is well known that dental characters vary with wear, and great care must be taken to sample taxa from medial stages of wear when comparing morphology (MacFadden, 1998). 


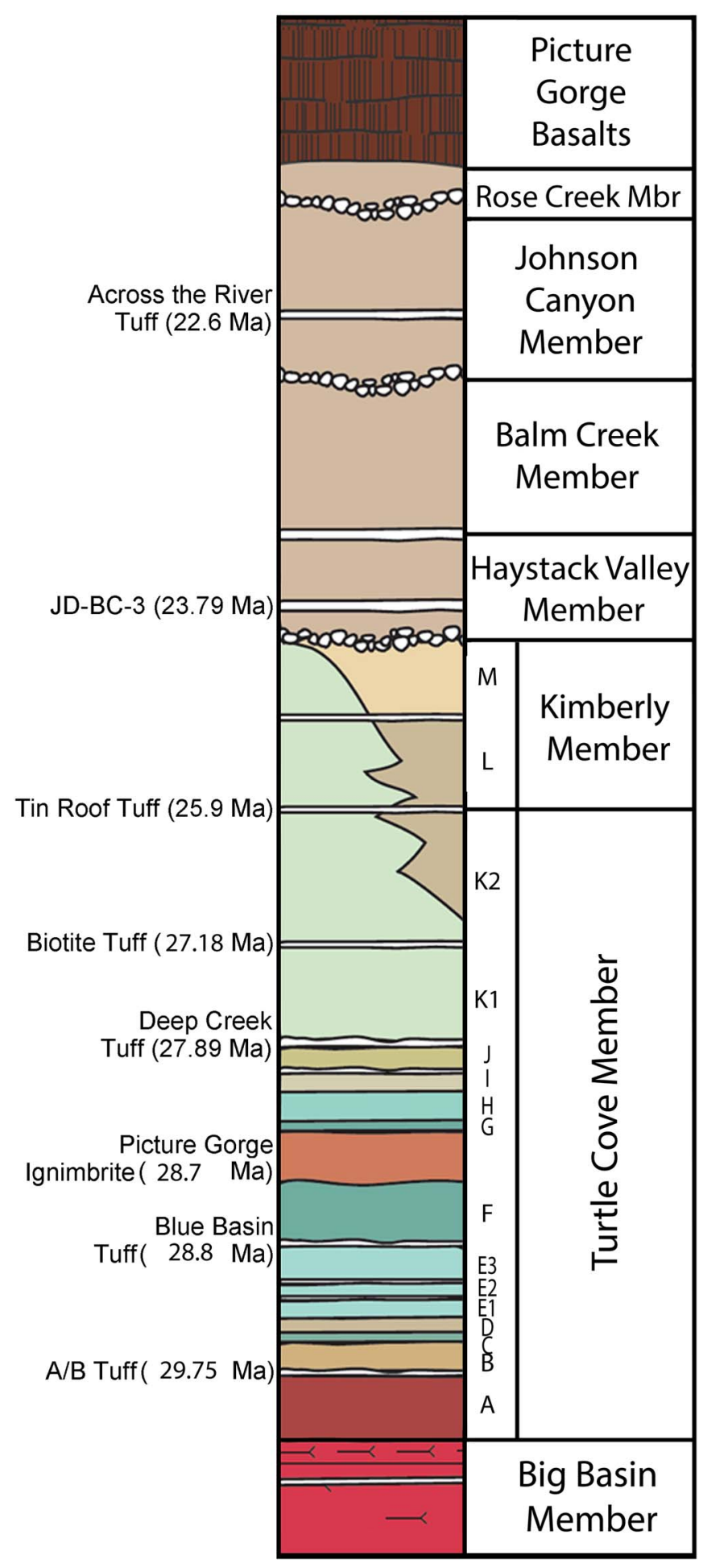

Figure 2. Composite stratigraphic section of the John Day Formation used in this study. Specimens are from the upper portion of the Big Basin, Turtle Cove, Kimberly, and Haystack Valley members. Specifically, specimens were recovered from Turtle Cove units A, B, C, D, undifferentiated layers in E, F, H, J, and K2 and Kimberly unit M. Specimens without a specific unit assigned could be from any unit within the assigned member. Additionally, the units described here are not always laterally continuous through all exposures of the Turtle Cove and Kimberly members, and may be undifferentiated in various localities.

Of all of the dental characters, hypostyle condition can be determined in all unbroken upper molars and premolars, and its differential morphology has been given the most emphasis when diagnosing species (Prothero and Shubin, 1989). Miohippus species from the Great Plains are primarily distinguished by anteriorposterior length of the tooth row and hypostyle condition when there is a lack of cranial and post-cranial material (Prothero and Shubin, 1989). Taphonomic processes in the John Day Formation tend to eliminate non-dental characters (e.g., skulls and postcrania), which tend to be more reliable in determining specieslevel identity, making it difficult or impossible to make such a determination on a majority of specimens. Furthermore, the validity of the presence and morphology of the facial fossa as valid characters has been debated for more derived equids (Alberdi, 1987; MacFadden, 1997) and has been called into question for early anchitherine equids (Masciale, 2010), and therefore should not be the sole basis of taxonomic assignment in Miohippus-grade equids. Prothero and Shubin (1989) focused on updating the taxonomy of the equids from the Oligocene White River Group of the Great Plains, but no taxonomic analyses have been conducted on those from the Oligocene John Day Formation of Oregon since Osborn (1918).

There is an ongoing debate regarding the presence of Mesohippus in the John Day Basin (Osborn, 1918; Fremd et al., 1994; Albright et al., 2008; Fremd, 2010). Most recently, Albright et al. (2008) recognized Mesohippus from the Big Basin Member to Turtle Cove Member Unit A, and Miohippus from the Turtle Cove Member Unit A to the Haystack Valley Member. In their study, Albright et al. (2008) never identified either taxon to species. Miohippus annectens from the John Day is the genotype and was also the first equid to be named from the John Day Basin (Marsh, 1874).

\section{Materials and methods}

I measured and examined 202 equid teeth (173 original specimens and 29 casts) at John Day Fossil Beds National Monument and the University of Oregon Museum of Natural and Cultural History (Table 1; Supplementary Data 1). Specimens included have been identified as Miohippus, Mesohippus, and Archaeohippus Gidley, 1906 (Supplementary Data Set 1). Additionally, measurements of the type specimen of Miohippus annectens and one additional specimen, held in the collections of the Yale Peabody Museum of Natural History, were taken from high-quality digital photographs using ImageJ (http://imagej.nih.gov/ij/). Removing these two specimens from my dataset does not change the outcome of the analysis. ImageJ is an open source program designed for analyzing images, including measuring length and area of structures and has become commonly used (e.g., Samuels, 2009; MeachenSamuels and Van Valkenburgh, 2010; Meachen-Samuels, 2012; Famoso et al., 2013; Farke and Wilridge, 2013; Vanderven et al., 2014; Vendrasco and Checa, 2015). Specimens come from throughout the exposures of the Big Basin, Turtle Cove, Kimberly, and Hasystack Valley members of the John Day Formation in eastern Oregon (Fig. 1; Table 1). Precise stratigraphic position for each specimen is recorded in Supplementary Data Set 1 when known. The anterior-posterior length (APL) and the transverse width (TW) of individual upper and lower molars and premolars and the mesostyle crown height were measured with a Mitutoyo Absolute Solar Digimatic CD-54"c digital caliper and a Pittsburgh 8" electronic digital caliper. The morphology of the hypostyle was also recorded. 
(1)
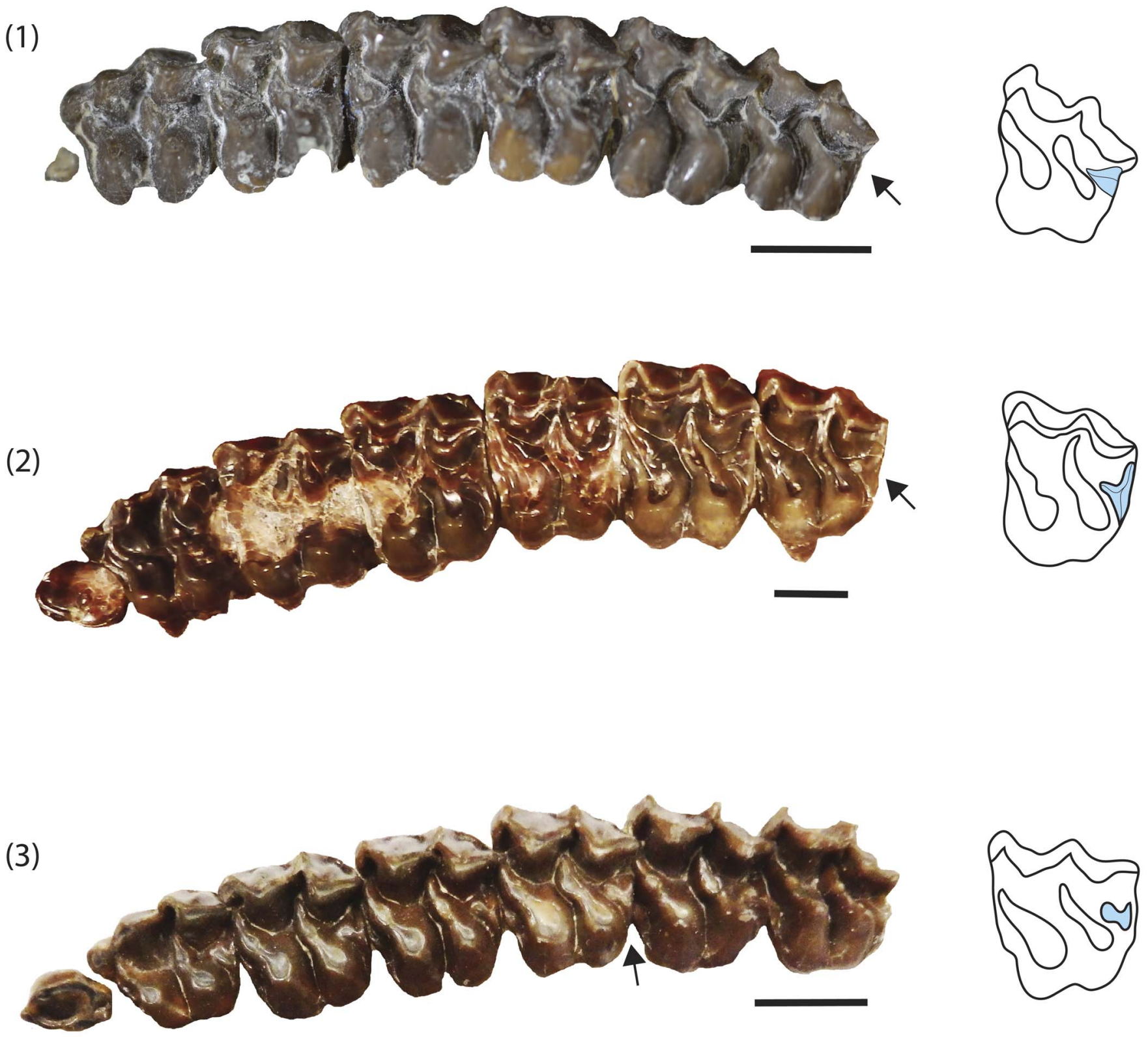

(4)
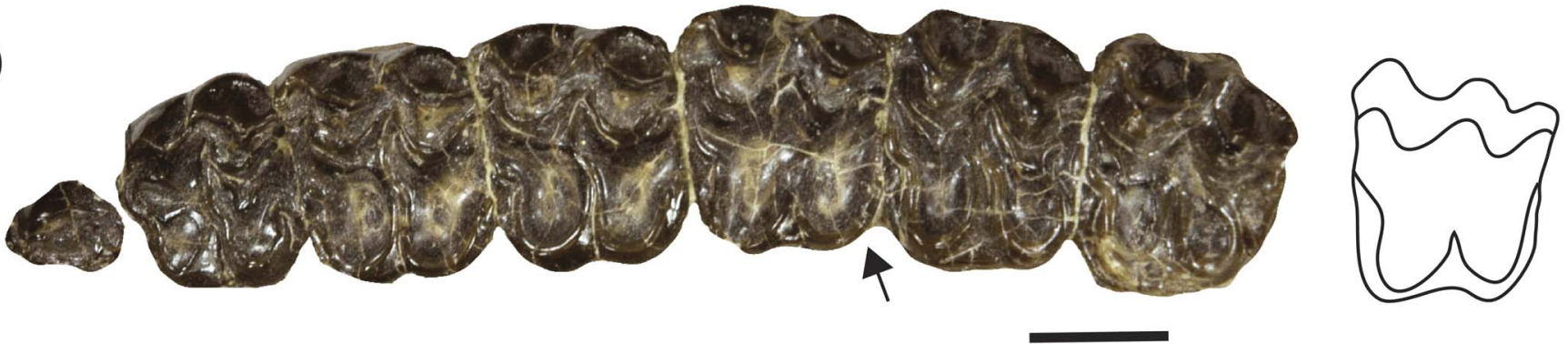

Figure 3. Representative examples of hypostyle conditions in Oligocene horses of the Turtle Cove assemblage of Oregon. Hypostyle condition follows the terminology of Prothero and Shubin (1989). (1) Type 1 hypostyles (UOMNH F-58207) are thin ridges that have no cusps or spurs projecting anteriorly; (2) Type 2 hypostyles (JODA 1086) exhibit a small spur, which projects anteriorly from the hypostyle ridge; (3) Type 3 hypostyles (UCMP 75274) are characterized by a small distinct ovoid or triangular pocket between a posterior ridge and an anterior spur; I have added the additional condition, (4) none (UCMP 75279), which I define as the lack of hypostyle in heavily worn teeth. Note that there are multiple hypostyle conditions contained within an individual tooth row. Arrows point to exemplar hypostyles on each tooth row that exhibit the specific condition. Line drawings of exemplar teeth are to the right of the photographs with the hypostyle highlighted in blue. Scale bars $=1 \mathrm{~cm}$. 
Table 1. Sample size of equid teeth for each stratigraphic unit in this study.

\begin{tabular}{lccccc}
\hline & $\begin{array}{c}\text { John Day } \\
\text { Formation }\end{array}$ & $\begin{array}{c}\text { Big } \\
\text { Basin } \\
\text { Member }\end{array}$ & $\begin{array}{c}\text { Turtle } \\
\text { Cove } \\
\text { Member }\end{array}$ & $\begin{array}{c}\text { Kimberly } \\
\text { Member }\end{array}$ & $\begin{array}{c}\text { Haystack } \\
\text { Valley } \\
\text { Member }\end{array}$ \\
\hline Upper (Indeterminate) & 27 & 1 & 21 & 3 & 1 \\
P2 & 12 & 0 & 6 & 2 & 0 \\
P3 & 11 & 0 & 5 & 2 & 0 \\
P4 & 14 & 0 & 8 & 2 & 0 \\
M1 & 16 & 0 & 9 & 3 & 0 \\
M2 & 19 & 0 & 12 & 3 & 0 \\
M3 & 20 & 0 & 12 & 4 & 0 \\
Lower (Indeterminate) & 19 & 1 & 16 & 0 & 1 \\
p1 & 0 & 0 & 1 & 0 & 0 \\
p2 & 8 & 0 & 5 & 1 & 0 \\
p3 & 5 & 0 & 1 & 2 & 0 \\
p4 & 6 & 0 & 3 & 0 & 0 \\
m1 & 12 & 0 & 8 & 1 & 0 \\
m2 & 15 & 0 & 12 & 1 & 0 \\
m3 & 18 & 0 & 12 & 2 & 0 \\
Total & 202 & 2 & 131 & 26 & 2 \\
\hline
\end{tabular}

The hypostyle is present in all unbroken upper teeth, unlike most other dental characters used to diagnose species. Furthermore, hypostyle morphology has been emphasized when diagnosing Miohippus species (Prothero and Shubin, 1989). Hypostyle condition follows the terminology of Prothero and Shubin (1989), but I have added the additional category "none," defined here as the lack of a hypostyle in heavily worn teeth (Fig. 3). Type 1 hypostyles are thin ridges that have no cusps or spurs projecting anteriorly. Type 2 hypostyles exhibit a small spur, which projects anteriorly from the hypostyle ridge. Type 3 hypostyles are characterized by a small distinct ovoid or triangular pocket between a posterior ridge and an anterior spur. Wear stage was approximated by using the mesostyle crown height and APL in a similar way to Hyposodonty Index (HI) of Van Valen (1960) for upper cheek teeth.

All data are presented in Supplementary Data 1. All other characters that have been used to differentiate genera and species (e.g., the articulation between the cuboid and third metatarsal, a longer face, and a deeper facial fossa) are not present in a majority of equid specimens from the John Day Formation. The taphonomy of the John Day Formation has resulted in a faunal assemblage where the most diagnostic skeletal elements for generic and specific identification are generally not preserved.

A Shapiro-Wilk W test (Shapiro and Wilk, 1965) was used to determine if APL and TW values were normally distributed (Gaussian distribution), which is an assumption of the parametric tests used in this study. Violations of this assumption would increase the possibility of Type II error. The coefficient of variation $(V)$, expressed as a percentage, is a metric used to test whether there is more variance than expected for a single species in fossil communities (Simpson and Roe, 1939; Cope and Lacey, 1992, 1995). $V$ was calculated for APL and TW of upper and lower teeth to determine whether the amount of variation present was greater than expected for a single-species population. Miller (1991) developed a method for comparing the fractional coefficients of variation $(\mathrm{CV})$ of two samples using the $t$ statistic.

The upper first molar (M1) of the sample of John Day Miohippus was compared to the published values for the modern equid Equus quagga Boddaert, 1785; the well-studied and relatively common Oligocene equid Mesohippus bairdii
Leidy, 1850 (MacFadden 1989) of the Great Plains; the coeval equid Miohippus equinanus (Prothero and Shubin, 1989) from Oregon; and the modern South American tapir Tapirus terrestris Linnaeus, 1758 (Colbert, 2006), which is a taxon also classified as a browser. It is important to note that $M$. bairdii could actually represent more than one species. The inclusion of M. bairdii in this study will help to not only to better understand the equid population in the Pacific Northwest, but will also begin to shed light on variation in the Great Plains species. Additionally, the lower first molar (m1) of the John Day Miohippus was compared to Tapirus terrestris. This study is constrained to the use of the M1 and $\mathrm{m} 1$ because of the availability of comparative data in the literature. The modern equid $E$. quagga was chosen as a comparative species because it is a decedent of John Day Miohippus, although from different subfamilies. Equus quagga allows for modern species variation of a closely related species to be directly compared to that of fossil assemblages. Mesohippus bairdii and M. equinanus are both extinct horses that would have been coeval with John Day Miohippus. Both species look fairly similar to John Day Miohippus, suggesting similar ecologies, and are also closely related. The modern South American tapir, T. terrestris, was chosen because it is a modern ecological analog to John Day Miohippus. Both are browsers and perissodactyls. They may not be as closely related as the other analog horse species, but they do share a relatively close ancestor compared to other modern browsers. Like E. quagga, T. terrestris allows for direct comparison of modern species variation to that of a fossil assemblage, although this is an ecological analog rather than direct descendent.

When calculating $V \mathrm{~s}$ on populations with small sample sizes $(\mathrm{n}<5)$, it is necessary to correct for small samples (Sokal and Braumann, 1980; MacFadden, 1989). If the calculated $t$ statistic is smaller than the critical $t$ statistic, I cannot reject the null hypothesis that the two $V \mathrm{~s}$ are the same, equating to a single-species null hypothesis. If I can reject the null hypothesis, then the observed $V$ value for the John Day Miohippus is in excess of the values of the analog taxa and is evidence for the presence of more than one species of Miohippus in the sample. The $p$-value was also calculated for the $t$ tests, and if any $p$-value is $>0.05$, I cannot reject the null hypothesis.

Hypostyle morphology was investigated using an ordered logistic regression with the ordinal package 2014.11-14 (Christensen, 2014) in R (R Core Team, 2013). The ordered logistic regression is a type of logistic regression where the order of the dependent variable matters. A logistic regression uses a nominal dependent variable and a continuous independent variable to determine if the variation in the continuous variable is responsible for the variation in the nominal variable, unlike a linear regression where the dependent variable is continuous. The ordered logistic regression is slightly different in that it uses an ordinal dependent variable and tests for differences between ordered pairs of the dependent variable. $\mathrm{HI}$ (a proxy for wear stage) was used as the independent variable, and hypostyle condition as the ordinal dependent variable. For this analysis, all tooth positions in the upper tooth row were used. Previous work has shown that occlusal enamel complexity, and by extension the occlusal enamel morphology, like the hypostyle morphology, is statistically similar in all molariform 
tooth positions in equids (Famoso and Davis, 2014). As such, this study assumes that hypostyle morphology is serially homologous between tooth positions at the same state of wear. Hypostyle condition type 1 should be less developed than type 2. Likewise, type 2 appears less developed than type 3 , and type 3 appears less developed than the final stage designated as none. If hypostyle condition is related to wear stage, then the hypostyle condition should be ordered and each ordered pair should be significant. However, if hypostyle condition is not related to tooth wear, then there would be no significant relationship between the ordered hypostyle condition pairs. R code is provided in Supplementary Data Set 2.

Repositories and Institutional Abbreviations.-AMNH FM: American Museum of Natural History, Division of Paleontology, New York, NY, USA; JODA: John Day Fossil Beds National Monument, United States National Park Service, Kimberly, OR, USA; UCMP: University of California Museum of Paleontology, Berkeley, CA, USA; UOMNH F-: University of Oregon Museum of Natural and Cultural History, Condon Fossil Collection, Eugene, OR, USA; UWBM: Burke Museum of Natural History and Culture, University of Washington, Seattle, WA, USA; YPM VP: Yale Peabody Museum of Natural History, Division of Vertebrate Paleontology, New Haven, CT, USA.

\section{Results}

None of the datasets violated the assumption of Gaussian distribution. The $V$ values and $t$ statistics for the APL and TW of the M1 of the John Day Miohippus, M. equinanus, Mesohippus bairdii, Equus quagga, and Tapirus terrestris are presented in Table 2. Interestingly, when all of the John Day equid material was lumped, the $t$ test was significant, suggesting more than one species was present. However, when specimens that were identified as Mesohippus, those from the Kimberly Member, and one specimen with uncertain locality and lithologic information were excluded, the $t$ test was not significant, suggesting only one species is present among those remaining specimens. The remaining specimens are only from the Turtle Cove Member. Each group, as defined earlier, was removed one at a time. Interestingly, when $M$. bardii was compared to the two modern taxa, E. quagga and T. terrestris, it was significantly different in both the APL and TW, suggesting that more than one species is present (Supplementary Data Set 1). The $V$ values and $t$ statistics for the APL and TW of the $\mathrm{m} 1$ of the Turtle Cove Miohippus and T. terrestris are also presented in Table 2. The calculations of $V$ and the $t$ statistic are provided in Supplementary Data Set 1 . Only the calculated $t$ statistics for the m1 TW between the Turtle Cove Miohippus and T. terrestris was significant. There is no significant difference between the $V$ in the Turtle Cove Miohippus and M. bairdii, M. equinanus, E. quagga, and T. terrestris, with the exception of the TW of the $\mathrm{m} 1$, as noted above (Table 2).

The ordered logistic regression was significant for all hypostyle condition pairs (Table 3). The ordered logistic regression was also significant when the M3 was removed. Each hypostyle condition was significantly different from the next
Table 2. Summary statistics for $t$ test. $V=$ Coefficient of Variation, $V^{\prime}=$ Coefficient of Variation (small sample size correction), $n=$ sample size, $S D=$ standard deviation, $\mathrm{APL}=$ anterior-posterior length, $\mathrm{TW}=$ transverse width, N/A = Not available. Mean values are in $\mathrm{mm}$.

\begin{tabular}{lcccc}
\hline & M1 APL & M1 TW & m1 APL & m1 TW \\
\hline VEqus quagga & 5.827 & 4.805 & N/A & N/A \\
V Turtle Cove Miohippus & 6.425 & 4.326 & 6.156 & 12.305 \\
VMesohippus bairdii & 9.821 & 8.262 & N/A & N/A \\
$V^{\prime}$ Miohippus equinanus & 5.856 & 4.012 & N/A & N/A \\
V Tapirus terrestris & 5.520 & 3.891 & 6.553 & 3.931 \\
Mean Equus quagga & 22.140 & 23.310 & N/A & N/A \\
Mean Turtle Cove Miohippus & 14.183 & 16.598 & 13.280 & 9.681 \\
Mean Mesohippus bairdii & 11.200 & 14.040 & N/A & N/A \\
Mean Miohippus equinanus & 11.100 & 13.500 & N/A & N/A \\
Mean Tapirus terrestris & N/A & N/A & N/A & N/A \\
SD Equus quagga & 1.290 & 1.120 & N/A & N/A \\
SD Turtle Cove Miohippus & 0.911 & 0.718 & 0.818 & 1.191 \\
SD Mesohippus bairdii & 1.100 & 1.160 & N/A & N/A \\
SD Miohippus equinanus & 0.600 & 0.500 & N/A & N/A \\
SD Tapirus terrestris & N/A & N/A & N/A & N/A \\
$n$ Equus quagga & 42 & 42 & N/A & N/A \\
$n$ Turtle Cove Miohippus & 11 & 8 & 5 & 5 \\
$n$ Mesohippus bairdii & 27 & 24 & N/A & N/A \\
$n$ Miohippus equinanus & 3 & 3 & N/A & N/A \\
$n$ Tapirus terrestris & 29 & 28 & 29 & 29 \\
$p$ value: Turtle Cove & 0.345 & 0.636 & N/A & N/A \\
$\quad$ Miohippus vs. Equus quagga & & & & \\
$p$ value: Turtle Cove & 0.921 & 0.955 & N/A & N/A \\
$\quad$ Miohippus vs. Mesohippus bairdii & & & & \\
$p$ value: Turtle Cove & 0.436 & 0.448 & N/A & N/A \\
$\quad$ Miohippus vs. Miohippus equinanus & & & & \\
$p$ value: Turtle Cove & 0.276 & 0.359 & 0.563 & $<0.001$ \\
Miohippus vs. Tapirus terrestris & & & & \\
\hline
\end{tabular}

Table 3. Summary statistics for ordered logistic regression. Wear $=$ Wear stage as approximated by Hypsodonty Index and represents the overall relationship between wear stage and hypostyle condidtion, $1 / 2=$ ordered test of hypostyle condition 1 and $2,2 \mid 3=$ ordered test of hypostyle condition 2 and 3,3 Inone $=$ ordered test of hypostyle condition 3 and none, $*=$ dependent variable. Hypostyle condition and wear stage appear as independent variables because the logistic regression tests both for a relationship with wear stage and for differences among ordered pairs.

\begin{tabular}{lcccc}
\hline & Value & Std. Error & $t$-value & $p$-value \\
\hline Wear & -16.197 & 2.903 & -5.580 & $<0.0001$ \\
$1 \mid 2 *$ & -9.717 & 1.407 & -6.907 & $<0.0001$ \\
$2 \mid 3^{*}$ & -7.192 & 1.192 & -6.031 & $<0.0001$ \\
$3 \mid$ none & -4.436 & 1.004 & -4.417 & $<0.0001$ \\
\hline
\end{tabular}

advanced stage, indicating that hypostyle condition is dependent on wear stage.

\section{Discussion}

The $V$ values found in the sample of the of Turtle Cove Miohippus population are not significantly different from the $V$ of any other sample of comparative taxa investigated in this study. Because the samples of comparative taxa used in this study are considered to be from populations containing a single species, my results suggest that the length and width of teeth observed in the Turtle Cove sample is what would be expected from a single horse population, or species concept. However, $M$. bardii may represent multiple species, given that its $t$ tests with modern analogs were significant. Species level diagnoses for Miohippus and Mesohippus use the APL as an important character (Prothero and Shubin, 1989), and it is clear from my results that more than one species of Turtle Cove Miohippus cannot be distinguished based upon the APL or TW. 
However, specimens of Mesohippus that were included in this study are significantly smaller than what is identified as Mesohippus, suggesting that a second species is present. The Kimberly Member specimens also represent a different species from the other Miohippus specimens.

The m1 TW of John Day Miohippus has a significantly different and relatively higher $V$ than that of Tapirus terrestris, the only other taxon in this study with $V$ for the lower dentition (Table 2). Both the TW and APL are measured at the base of the crown, thus eliminating wear as a confounding factor. MacFadden (1989) found that the TW and APL of the M1 were not consistently related and concluded that the variation of fossil equids is similar in a majority of cases. Therefore, it is not unusual to have the TW be more variable than the APL.

The data suggest that there are at least two species of horse present in the Turtle Cove Member-a larger morph, Miohippus, and a smaller morph, Mesohippus. There is not enough material to justify a species-level identification for the Mesohippus material. The species-level identification of Miohippus is likely to be M. annectens. Provinciality and taxonomic priority can be invoked to support this identification. Additionally, the type specimen of $M$. annectens was included in the analysis, further justifying this taxonomic assignment. Miohippus annectens has priority in this situation because it is the genotype species of Miohippus and was the first species described from the John Day Formation.

The ordered logistic regression demonstrated that the hypostyle condition was dependent on wear stage for John Day Miohippus. The spread in the variance may be the result of including all tooth positions in the analysis; however, when M3 is removed, the result is unchanged. Further analysis with a larger sample size should consider tooth position because it has been shown to be a significant factor in occlusal morphology of ungulates (Famoso et al., 2013). This is an interesting result because the hypostyle condition has been used as a character to differentiate among species of Miohippus, and even between Miohippus and Mesohippus in the Great Plains (Prothero and Shubin, 1989). As a result, the validity of the hypostyle as a character is called into doubt. Future work to resolve the number of species in the "Anchitheriinae" will need to take wear into account because wear stage is an important factor when dealing with ungulate dentition.

The identification of equid teeth is often confounded by the wear stage of the tooth. For example, the occlusal morphology of hypsodont equid teeth is often used to diagnose tribes, genera, and species. The two major tribes of hypsodont equids, Hipparionini and Equini, are often diagnosed by whether the protocone is connected (Equini) or isolated (Hipparionini). The hipparionine genus Pseudhipparion has a protocone that is isolated in early wear and connected in late stages of wear, and in the equine genus Protohippus, the protocone is isolated in relatively early wear and connected in later wear (MacFadden, 1998). In this case, identification at the tribal level is far from trivial without considering wear stage. Attention to tooth wear is paramount when identifying teeth from these taxa because they are coeval in the Miocene of North America (MacFadden, 1998; Famoso and Pagnac, 2011). It is not surprising that wear stage is also important to the identification of dental material from lower-crowned anchitherine equids like Miohippus. Consideration of wear in these low-crowned taxa should be adopted when considering the ubiquitous dental characters used to diagnose equids of Miohippus-grade.

Some species of Miohippus are distinguished based on non-dental characters, which were not present in this analysis. It may be possible to analyze the John Day Miohippus population more completely once sufficient non-dental material is acquired and appropriate methods are developed. However, these characters may prove to be less useful in light of statistical methods. Future work should focus on non-dental morphology if sufficient material is collected.

Statistical methods will better inform analyses that address the continent-wide issue of distinguishing Mesohippus from Miohippus. These two genera are difficult to distinguish (Stirton, 1940), but are considered distinct based on the presence and condition of the articular facet on the third metatarsal, which articulates with the cuboid; larger hypostyles; a longer face; and a deeper facial fossa (Prothero and Shubin, 1989; MacFadden, 1998). The paleopopulation of John Day Miohippus is not adequate in addressing this issue because there are only five occurrences of Mesohippus in the entire assemblage. Very few specimens from the Turtle Cove assemblage were identified as Mesohippus, and those that were identified as such were determined to be statistically different from the specimens of Miohippus. In the end, a larger sample size of all equid taxa from the John Day Formation would be necessary to get at more nuanced differences among these genera and species. In the geographically limited area of this study where many species have previously been reported, there is no statistically significant evidence for the presence of more than a single species of Miohippus. Applying these techniques to the Miohippus recovered from the Great Plains would likely lead to reduction in the number of species. The results from the $t$ tests between $M$. bardii of the Great Plains do suggest that multiple species are present within that population, warranting further analyses. Statistical analyses of dental variation have shown great utility in assessing species-level diversity in the small, geographically constrained, paleopopulation of the Turtle Cove assemblage, therefore the application of these methods to the continent-wide issue seems promising.

The dental variation of Miohippus considered herein from the Turtle Cove Member is not statistically different from other populations of similar perissodactyls, both extinct and extant. The hypostyle condition cannot be used to differentiate species in this population because it is dependent on wear. It is clear that the confounding effects of wear on dental morphology need to be considered even in low-crowned equids like Miohippus. Two species of equid in the Turtle Cove Member of the John Day Formation can be recognized based on analysis of dental characters, which have been used to diagnose species of Miohippus and Mesohippus in the Great Plains. Based on the available dental material, there is no statistical or morphological variation in the sample of Turtle Cove Miohippus in excess of the variation seen in a single analog species. Specimens of Mesohippus do represent a different species, as do the specimens from the Kimberly Member, which include Archaeohippus and Miohippus longiceps. As a result, only Miohippus annectens, the genotype and first species recognized in the Turtle Cove Member, can be recognized as the sole species of equid in the Turtle Cove assemblage (Marsh, 1874). 


\section{Acknowledgments}

I thank the Geological Society of America GeoCorps America program, which supported me while conducting research at John Day Fossil Beds National Monument. I also thank R. Dunn for assistance in obtaining locality names for Burke Museum of Natural History and Culture specimens, and C. Norris and D. Brinkman for providing photos of Yale Peabody Museum of Natural History specimens. Photos of University of California Museum of Paleontology specimens were taken while I was supported by the Doris O. and Samuel P. Welles Research Fund and by E. Holt. P.A. Holroyd, K. Bredehoeft, and C. Schierup assisted me with specimens in their respective collections. I especially thank J.X. Samuels for initially asking me to determine how many horse species were present in the Turtle Cove assemblage while working as a GeoCorps volunteer. Thanks are extended to M.M. Emery, S.S.B. Hopkins, and J. Calede for thoughtful discussions. I also thank J.X. Samuels, E.B. Davis, and J.D. Orcutt for feedback with this project and on earlier versions of this manuscript. B. Hunda, E. Scott, and anonymous reviewers provided valuable reviews that greatly improved this manuscript.

\section{Accessibility of supplemental data}

Data available from the Dryad Digital Repository: http://doi. org/10.5061/dryad.2p164

\section{References}

Alberdi, M.T., 1987, La Familia Equidae, Gray 1821 (Perissodactyla, Mammalia) em El Pleistoceno de Sudamérica. IV Congreso Latinoamericano de Paleontologia , Bolivia 1: p. 484-499.

Albright, L.B., III, Woodburne, M.O., Fremd, T.J., Swisher, C.C., III, MacFadden, B.J., and Scott, G.R., 2008, Revised chronostratigraphy and biostratigraphy of the John Day Formation (Turtle Cove and Kimberly members), Oregon, with implications for updated calibration of the Arikareean North American Land Mammal Age: The Journal of Geology, v. 116, p. 211-237.

Boddaert, P., 1785, Elenchus Animalium, v. 1. Sistens quadrupedia huc usque nota, eorumque varietates: ad ductum naturae, quantum fieri potuit disposita: Roterodami, Apud C.R. Hake, 174 p.

Christensen, R.H.B., 2014, ordinal - Regression Models for Ordinal Data. R package version 2014.11-14. http://www.cran.r-project.org/package=ordinal/

Colbert, M.W., 2006, Variation and species recognition in Eocene tapirs from Southern California: Journal of Vertebrate Paleontology, v. 26, p. 712-719.

Cope, E.D., 1878, On some of the characters of the Miocene Fauna of Oregon: Proceedings of the American Philosophical Society, v. 18, p. 63-78.

Cope, D.A., and Lacy, M.G., 1992, Falsification of a single species hypothesis using the coefficient of variation: a simulation approach: American Journal of Physical Anthropology, v. 89, p. 359-378.

Cope, D.A., and Lacy, M.G., 1995, Comparative application of the coefficient of variation and range-based statistics for assessing the taxonomic composition of fossil samples: Journal of Human Evolution, v. 29, p. 549-576.

Famoso, N.A., and Davis, E.B., 2014, Occlusal enamel complexity in middle Miocene to Holocene Equids (Equidae: Perrisodactyla) of North America: PLoS ONE, v. 9(2), p. 1-11.

Famoso, N.A., and Pagnac, D.C., 2011, A comparison of the Clarendonian equid assemblages from the Mission Pit, South Dakota and Ashfall Fossil Beds, Nebraska: Transactions of the Nebraska Academy of Sciences, v. 32, p. $98-107$.

Famoso, N.A., Feranec, R.S., and Davis, E.B., 2013, The relationship between lophodonty, hypsodonty, body mass and diet in extinct and extant ungulates: Palaeogeography, Palaeoclimatology, Palaeoecology, v. 387, p. 211-216.

Farke, A.A., and Wilridge, C.A., 2013, A possible pterosaur wing phalanx from the Kaiparowits Formation (Late Campanian) of Southern Utah, USA: PalArch's: Journal of Vertebrate Palaeontology, v. 10, p. 1-6.
Fremd, T.J., 2010, Guidebook: SVP Field Symposium 2010. John Day Basin Field Conference, John Day Fossil Beds National Monument (and surrounding basin), Oregon, USA: Society of Vertebrate Paleontology, p. $1-153$.

Fremd, T.J., Bestland, E.A., and Retallack, G.J., 1994, John Day Basin Paleontology Field Trip Guide and Road Log: Society of Vertebrate Paleontology Annual Meetings, p. 1-80.

Gidley, J.W., 1906, A new genus of horse from the Mascall beds, with notes on the small collection of equine teeth in the University of California: Bulletin of the American Museum of Natural History, v. 22, p. 385-388.

Hunt, R.M., and Stepleton, E., 2004, Geology and paleontology of the upper John Day beds, John Day River Valley, Oregon: lithostratigraphic and biochronologic revision in the Haystack Valley and Kimberly areas (Kimberly and Mt. Misery quadrangles): Bulletin of the American Museum of Natural History, v. 282, p. 1-90.

Leidy, J., 1850, Description of Rhinoceros nebrascensis, Agriochoerus antiquus, Palaeotherium proutii, and Palaeotherium bairdii: Proceedings of the Academy of Natural Sciences, Philadelphia, v. 5, p. 121-122.

Leidy, J., 1869, On the extinct Mammalia of Dakota and Nebraska, including an account of some allied forms from other localities, together with a synopsis of the mammalian remains of North America: Proceedings of the Academy of Natural Sciences, Philadelphia, v. 7, n. 2, p. 1-472.

Leidy, J., 1870, Remarks on a collection of fossils from the western territories: Proceedings of the Academy of Natural Sciences of Philadelphia, v. 22, p. $109-110$.

Linnaeus, C., 1758, Systema Naturae per Regna tria Naturae, secundum Classes, Ordines, Genera, Species, cum Characteribus, Differentiis, Synonymis, Locis, 10th edition: Stockholm, Holmiæ, 824 p.

MacFadden, B.J., 1986, Fossil horses from "Eohippus" (Hyracotherium) to Equus: scaling, Cope's Law, and the evolution of body size: Paleobiology, v. 12 , p. $355-369$.

MacFadden, B.J., 1989, Dental character variation in paleopopulations and morphospecies of fossil horses and extant analogs, in Prothero, D.R., and Schoch, R.M., eds., The Evolution of Perissodactyls: New York, Oxford University Press, p. 128-141.

MacFadden, B.J., 1997, Pleistocene horses from Tarija, Bolivia, and validity of the genus Onohippidium (Mammalia: Equidae): Journal of Vertebrate Paleontology, v. 17, p. 199-218.

MacFadden, B.J., 1998, Equidae, in Janis C.M., Scott, K.M., and Jacobs L.L., eds., Evolution of Tertiary Mammals of North America, v.1: New York, Cambridge University Press, p. 537-559.

Marsh, O.C., 1874, Notice of new equine mammals from the Tertiary formation: American Journal of Science and Arts, v. 7, n. 3, p. 249-250.

Marsh, O.C., 1875, Notice of new Tertiary mammals: American Journal of Science, v. 9, n. 3, p. 239-250.

Masciale, D.M., 2010, An Analysis of Anchitherine Equids Across the EoceneOligocene Boundary in the White River Group of the Western Great Plains [M.S. thesis]: Lincoln, University of Nebraska, 79 p.

Meachen-Samuels, J.A., 2012, Morphological convergence of the prey-killing arsenal of sabertooth predators: Paleobiology, v. 38, p. 1-14.

Meachen-Samuels, J.A., and Van Valkenburgh, B., 2010, Radiographs reveal exceptional forelimb strength in the sabertooth cat, Smilodon fatalis: PLoS ONE, v. 5(7), p. e11412.

Miller, G.E., 1991, Asymptotic test statistics for coefficients of variation: Communications in Statistics-Theory and Methods, v. 20, p. 2251-2262.

Osborn, H.F., 1915, [No title; description of Kalobatippus gen. nov.], in Cope, E.D., and Matthew W.D. eds. Hitherto unpublished plates of Tertiary Mammalia and Permian Vertebrata: U.S. Geological Survey and American Museum of Natural History, Monograph Series 2, Plate 58.

Osborn, H.F., 1918, Equidae of the Oligocene, Miocene, and Pliocene of North America, iconographic type revision: Memoirs of the American Museum of Natural History, v. 2, p. 1-217.

Prothero, D.R., and Shubin, N., 1989, The evolution of Oligocene horses, in Prothero, D.R., and Schoch, R.M., eds., The Evolution of Perissodactyls: New York, Oxford University Press, p. 142-175.

R Core Team, 2013, R: A language and environment for statistical computing: $\mathrm{R}$ Foundation for Statistical Computing, Vienna, Austria. http://www. R-project.org/

Retallack, G.J., Bestland, E.A., and Fremd, T.J., 2000, Eocene and Oligocene paleosols of central Oregon: Geological Society of America Special Papers, v. 344 , p. $1-192$.

Samuels, J.X., 2009, Cranial morphology and dietary habits of rodents: Zoological Journal of the Linnean Society, v. 156, p. 864-888.

Seligman, A.N., Bindeman, I.N., McClaughry, J., Stern, R.A., and Fisher, C., 2014, The earliest low and high $\mathrm{d}^{18} \mathrm{O}$ caldera-forming eruptions of the Yellowstone plume: implications for the 30-40 Ma Oregon calderas and speculations on plume-triggered delaminations: Frontiers in Earth Science, v. 2, p. 1-34.

Shapiro, S.S., and Wilk, M.B., 1965, An analysis of variance test for normality (complete samples): Biometrika, v. 52, p. 591-611. 
Simpson, G.G., and Roe, A., 1939, Quantitative Zoology: Numerical concepts and methods in the study of recent and fossil animals: New York, McGraw-Hill, $414 \mathrm{p}$.

Sinclair, W.J., 1905, New or imperfectly known rodents and ungulates from the John Day Series: University of California Publication Bulletin of the Department of Geology, v. 4, p. 1-141.

Sokal, R.R., and Braumann, C.A., 1980, Significance tests for coefficients of variation and variability profiles: Systematic Zoology, v. 29, p. 50-66.

Stirton, R.A., 1940, Phylogeny of North American Equidae: University of California Publications in Geological Sciences, v. 25, p. 165-198.

Van Valen, L., 1960, A functional index of hypsodonty: Evolution, v. 14, p. $531-532$
Vanderven, E., Burns, M.E., and Currie, P.J., 2014, Histologic growth dynamic study of Edmontosaurus regalis (Dinosauria: Hadrosauridae) from a bonebed assemblage of the Upper Cretaceous Horseshoe Canyon Formation, Edmonton, Alberta, Canada: Canadian Journal of Earth Sciences, v. 51, p. $1023-1033$.

Vendrasco, M.J., and Checa, A.G., 2015, Shell microstructure and its inheritance in the calcitic helcionellid Mackinnonia: Estonian Journal of Earth Sciences, v. 64, p. $99-104$.

Accepted 24 April 2017 